\title{
Investment feasibility and marketing of mangosteen commodity in Central Sulawesi, Indonesia
}

\author{
Marianne Reynelda Mamondol \\ Study Program of Agribusiness, Christian University of Tentena, Poso, Central Sulawesi, Indonesia \\ *Correspondence email: mariannemamondol@gmail.com
}

\section{ARTICLE INFO}

- Research Article

Article History

Received 23 June 2020

Accepted 7 September 2020

Published 31 October 2020

\section{Keywords}

feasibility; marketing; sensitivity; Sulawesi; tropical fruit

JEL Classification

D25; O22; Q13

\begin{abstract}
The development of mangosteen agribusiness in the regions needs attention to benefit local economic development. This research aims to analyze the investment and marketing feasibilities of mangosteen commodity at Olumokunde Village, Poso Regency, Central Sulawesi, Indonesia. Research respondents, as many as 60 farmers, were determined through stratified sampling technique. Data collection was done through observations, interviews, questionnaires to respondents, and documentary study. Research results demonstrate that mangosteen farms meet investment feasibility. The research found that the indicator of net present value was 87.496 million rupiahs, the internal rate of return was $19.8 \%$ and the payback period was 10.95 years. Since its 7th year, the mangosteen farm business' amount of revenue has been higher than its operational costs. Also, the research reveals farm sensitivity on the changes of cost production, selling price, and mangosteen production. There are two models of mangosteen fruit marketing channel at Olumokunde: (i) direct marketing from farmers to consumers, and (ii) indirect marketing through fruit wholesalers. The mangosteen agribusiness development needs regional government intervention in the forms of facility and infrastructure requirement as well as supply chain strengthening in order to create large-scale, economical, and highly competitive farms.
\end{abstract}

Citation: Mamondol, M. R. (2020). Investment feasibility and marketing of mangosteen commodity in Central Sulawesi, Indonesia. Journal of Socioeconomics and Development, 3(2), 115-125. https://doi.org/10.31328/jsed.v3i2.1433

\section{INTRODUCTION}

One of the very popular tropical fresh fruit commodities is mangosteen (Garcinia mangostana L.), also called "The Queen of Fruit" (Asmara et al., 2011) Mangosteen has typical tastes of sweet and sour, and a unique rind color of purplish red. Being consumed in the form of fresh fruit, almost all parts of mangosteen such as flesh, rind, and seed can be processed to increase its commercial value. Mangosteen processed products include coloring substance, rind flour, juice, cocktail, syrup, and rind herbal extract. Mangosteen contains antioxidant compounds that are very beneficial for human health such as anthocyanin, xanthone, tannin, and phenolic acid (Narakusuma et al., 2013)

In Indonesia, mangosteen planting centers are located in several regions such as West Java (Purwakarta, Bogor, Tasikmalaya, and Ciamis), West Sumatera, North Sumatera, Riau, East Java, East Kalimantan, Central Kalimantan, and Bali. West Java and West Sumatera become the biggest mangosteen producers in Indonesia, with production volume as high as 11.5 and 8.5 thousand tons respectively in the year of 2015 . The average production rate of 
Indonesian mangosteen during 1993-2013 period was 63.7 thousand tons annually, while the average export volume in the same period reached 7.85 thousand tons per year (Ashari et al., 2015). Mangosteen export ranks first on national fresh fruit export to foreign countries. Kusmayadi et al. (2017) argued that the level of consumption of mangosteen was higher than that of other fruits, especially because of its benefits on health. Therefore this becomes an opportunity for mangosteen agribusiness development in Indonesia to meet marketing needs, both domestic and international.

Nevertheless, in the current era of trade globalization, Indonesian mangosteen products should deal with intense competition with similar products from other countries in domestic and international markets. Indonesia's main competitors of mangosteen producers are India, China, and Thailand, whose market shares have increased since 2009 (Kustiari et al., 2012).

Generally, the problem encountered by farmers is the low quality of fruits produced. The contributing factors include traditional cultivation practices, such as the lack of fertilization on crops, the number of mangosteen trees over 30 years whose productivity level has decreased, and the use of non-superior seedlings (Suminartika, 2017). Limited capital is also an obstacle in improving mangosteen quality at the farmer level. The lack of capital forces the farmers to not fertilize their crops, only spending their small amount of fund for harvesting and weeding labors. This means that farmers do not carry out the process of crop cultivation as recommended.

Mangosteen is among fruit commodities which are cultivated by many people in Poso Regency. As an effort to encourage the development of horticultural production, specifically the mangosteen commodity, the regional government of Poso Regency has established East Pamona District as a location for mangosteen crop development. The agriculture sector program that refers to the MidTerm Regional Development Plan of Poso Regency for 2016 to 2021 has appointed Olumokunde Village, one of 13 villages in East Pamona District, as a model for developing agribusiness-based agricultural center. Initiated by Poso Regency Agriculture Office, the local government has implemented the declaration of Olumokunde as The Mangosteen Village ("Kampung Manggis") on September 29, 2017.
Potentials for developing mangosteen crops as an alternative effort to enhance farmer's household income is very promising, given that before the launching of the regional government program, mangosteen farms were able to provide additional income to farmers' families as much as 1.00 to 1.25 million rupiahs per tree each year on average. A preliminary survey confirmed that the yield of mangosteen fruits obtained by farmers at Olumokunde was as many as 100 to $125 \mathrm{~kg}$ with an average selling price of $\mathrm{Rp} 10,000$ per $\mathrm{kg}$. The village's fruit yield of 100 to $125 \mathrm{~kg}$ per tree was greater than that of the Central Sulawesi region which reached $96 \mathrm{~kg}$ per tree (BPS Provinsi Sulawesi Tengah, 2017), but still lower than that produced by farmers at Sukabumi Regency, West Java (204 $\mathrm{kg} /$ tree/year) (Nuraniputri et al., 2016), as well as results from farmers at Thailand, Malaysia, and India (300 kg/tree/year) (Nuraniputri et al., 2016). The reason for this is that Olumokunde farmers generally still expect productions from trees that are over 30 years old, have not used seedlings from superior clones, have no application of cultivation technology based on operational standard procedures that refers to Good Agricultural Process and Good Handling Practices concepts, and deal with a weak integrated supply chain in business partnership (Saptana et al., 2018)

To attract farmers or investors, there should be pieces of information about the feasibility of mangosteen farm. Thus, to determine how a project can be beneficial or not, a study of the project evaluation needs to be done. Santos et al. (2017) in their research about the financial feasibility of coffee monoculture farming in Emera District, East Timor used several criteria such as Net Present Value (NPV), Internal Rate of Return (IRR), Gross B/C Ratio, Net B/C Ratio, payback period, and sensitivity analysis to certain that investment decision was feasible. Gogic \& Ivanovic (2013) applied the indicators of NPV, IRR, and payback period to determine the investment feasibility in raspberry plantations in Serbia. Whereas Shruthi et al. (2017) studied the financial feasibility of paddy precision farming in India by using the criteria of NPV, IRR, Net and Gross B/C Ratios, payback period, and profitability index. Eventually, study results of investment feasibility will give two choices to farmers or investors whether they can invest in a project or save the money in the bank (Dhakal et al., 2016). 
Marketing analysis was carried out to discover the model of the mangosteen marketing channel which was applicable at the study site. Agricultural marketing can be defined as the commercial functions involved in transferring products consisting of a farm, horticultural, and other allied products from producer to consumer. Agricultural marketing includes all activities involved in moving agricultural products from producer to consumer through time (storage), space (transport), form (processing), and transferring ownership at various levels of marketing channels (Rehman et al., 2012). Since mangosteen is highly perishable, according to Gopalakhrisnan (2013), it needs careful handling, quick transport, sound packaging, and timeliness of all operations.

Naseer et al. (2019) in their study regarding citrus marketing in Pakistan stated that there are two models of the fruit supply chain: (i) traditional supply chain which sells directly to village retailers, local intermediaries, or traditional markets, and (ii) modern supply chain which sells to traders, contractors, local processors, or manufacturing factories. The form of marketing channel will determine both the revenue obtained by farmers and the bargaining position on their products (Asogwa \& Okwoche, 2012).

This study discusses the concept of mangosteen farm development at Olumokunde Village in the form of plantation business which is assumed to have met the technical requirements for crop cultivation so that the crops are expected to be able to produce optimally and provide a reasonable profit for farmers who work on them. Investment analysis was conducted to find out farm feasibility for 25 years of investment period by the entrepreneur. According to Al-Sharafat \& Al-Fawwaz (2013), some indicators provided reasonable and reliable tools to conduct a financial feasibility analysis as a procedure to achieve the goals of any feasibility study. The scope of the feasibility of this study is limited to investment decisions made by entrepreneurs to develop their farms. The study result is expected to be referenced for all stakeholders related to the development of mangosteen commodity and growth of the market for fruit products that is profitable for business actors and regional economic development.

This research aims to analyze the investment feasibility and marketing of mangosteen commodity at Olumokunde Village, Poso Regency, Central Sulawesi, Indonesia.

\section{RESEARCH METHOD}

This research was conducted at Olumokunde Village, East Pamona District, Poso Regency, Central Sulawesi, Indonesia from June to September 2018. Research respondents of 60 mangosteen farmers from a population of 115 farmers were determined through a stratified sampling technique based on the mangosteen cultivation area. There were 3 categories of size area, i.e. less than 1 ha, 1 to 5 ha, and more than 5 ha. From each category 20 farmers were taken as respondents. Data obtained from all respondents were then averaged to become a calculation of farm analysis as large as 1 ha.

The collected data consisted of primary data and secondary data. The primary data consisted of mangosteen fruit production, selling price, the use of production facilities and farm labors, and fruit product distribution from farmer to the trader and or consumer. The secondary data included geographic condition and village's climate from both Central Bureau of Statistics of Poso Regency (BPS Poso) and Meteorological, Climatological, and Geophysical Agency of Central Sulawesi Province (BMKG Sulawesi Tengah). Data collection was done through a survey method in the forms of field observation, questionnaire to respondents, interview, and documentary study for secondary data.

Data were then analyzed using income analysis, $\mathrm{R} / \mathrm{C}$ ratio, farm financial feasibility analysis (calculations of NPV, IRR, gross $B / C$ ratio, net $B / C$ ratio, profitability ratio, and payback period), farm sensitivity analysis, and mangosteen marketing channel analysis. The methods of analysis can be explained as follows.

Income calculation is done using the formula:

$$
\Pi=\mathrm{TR}-\mathrm{TC}
$$

in which $\Pi$ is mangosteen farm income (rupiah/ha/ year), TR is total revenue (rupiah/ha/year), TC is total cost production (rupiah/ha/year)

$\mathrm{R} / \mathrm{C}$ Ratio is calculated with the formula:

$$
\mathrm{R} / \mathrm{C} \text { Ratio }=\frac{\mathrm{TR}}{\mathrm{TC}}
$$

$\mathrm{R} / \mathrm{C}$ Ratio is a value that shows the ratio between the amount of revenue and farm production costs. A value of $\mathrm{R} / \mathrm{C}$ Ratio lower than 1 means that the farm is a loss, $R / C$ Ratio equals 1 means that the farm is break-even, and R/C Ratio higher than 1 means that farm gets profit. 
Net Present Value (NPV) is the difference between present value and invested initial capital. NPV $\geq 0$ means go project, or investment is feasible to be performed. In another word, a project can generate benefits that have the same as or more value than overall expenses

$$
\mathrm{NPV}=\sum_{\mathrm{t}=1}^{\mathrm{n}}\left(\mathrm{B}_{\mathrm{t}}-\mathrm{C}_{\mathrm{t}}\right) /(1+\mathrm{i})^{\mathrm{t}}-\mathrm{K}_{0}
$$

in which $\mathrm{K}_{0}$ is investment cost, $(\mathrm{Bt}-\mathrm{Ct}) /(1+\mathrm{i})^{\mathrm{t}}$ is NPV in the relevant years, $B$ is benefit and $C$ is cost.

Internal Rate of Return (IRR) or investment rate is a level of rate which points out that the amount of NPV is the number of overall investment costs. For investment decision making, IRR is compared with the social discount rate, and equals to the bank interest rate. IRR $\geq$ social discount rate means go project.

$$
\operatorname{IRR}=\sum_{\mathrm{t}=1}^{\mathrm{n}}\left(\mathrm{B}_{\mathrm{t}}-\mathrm{C}_{\mathrm{t}}\right) /(1+\mathrm{i})^{\mathrm{t}}=0
$$

Gross Benefit-Cost Ratio (Gross B/C Ratio) is a ratio between the amount of present value of the gross benefit and the amount of present value of gross cost. Gross B/C Ratio $\geq 0$ means that investment is feasible to be performed.

$$
\text { Gross B/C Ratio }=\frac{\sum_{\mathrm{t}=1}^{\mathrm{n}} \mathrm{B}_{\mathrm{t}} /(1+\mathrm{i})^{\mathrm{t}}}{\sum_{\mathrm{t}=1}^{\mathrm{n}} \mathrm{C}_{\mathrm{t}} /(1+\mathrm{i})^{\mathrm{t}}}
$$

Net Benefit-Cost Ratio (Net B/C Ratio) is a ratio between the amount of positive present value and the amount of negative present value. Net B/C Ratio $\geq 0$ means that investment is feasible to be performed.

$$
\text { Net B/C Ratio }=\frac{\sum_{\mathrm{t}=1}^{\mathrm{n}}\left(B_{t}-C_{t}\right)-(1+i)^{t}}{\sum_{\mathrm{t}=1}^{\mathrm{n}}\left(C_{t}-B_{t}\right)-(1+i)^{t}}
$$

Profitability Ratio $\left(\mathrm{PV}^{\prime} / \mathrm{K}\right)$ or capital rentability index or profitability ratio is a ratio between the present value of the residual benefit flow minus the routine cost and the present value of capital cost. $\mathrm{PV}^{\prime} / \mathrm{K} \geq 0$ means that investment is feasible to be performed.

$$
\mathrm{PV}^{\prime} / \mathrm{K}=\frac{\sum_{\mathrm{t}=1}^{\mathrm{n}}(\mathrm{Bt}-\mathrm{O} \& \mathrm{M}) /(1+\mathrm{i})^{\mathrm{t}}}{\sum_{\mathrm{t}=1}^{\mathrm{n}} \mathrm{K}_{\mathrm{t}} /(1+\mathrm{i})^{\mathrm{t}}}
$$

$\mathrm{O}$ and $\mathrm{M}$ are operational and maintenance costs, and $\mathrm{Kt}$ is capital cost.

Payback period is a period during which net cash flow can recoup all investment costs incurred. The faster the payback period is for an investment, the more economically profitable an investment is carried out.

$$
\sum_{\mathrm{t}=0}^{\mathrm{n}} \mathrm{Bt}-\mathrm{Ct}=\mathrm{K}_{0}
$$

The sensitivity rate of investment criteria to the factors that influence them is calculated by the formula:

Sensitivity rate $=\frac{\frac{\left|\mathrm{X}_{1}-\mathrm{X}_{0}\right|}{|\overline{\mathrm{X}}|} \times 100 \%}{\frac{\left|\mathrm{Y}_{1}-\mathrm{Y}_{0}\right|}{|\overline{\mathrm{Y}}|} \times 100 \%}$

in which $X_{1}$ is NPV, IRR, Gross $B / C$, Net $B / C, P V^{\prime} / K$, Payback period after changes; $X_{0}$ is NPV, IRR, Gross $\mathrm{B} / \mathrm{C}$, Net $\mathrm{B} / \mathrm{C}, \mathrm{PV}^{\prime} / \mathrm{K}$, Payback period before changes; $\bar{X}$ is the average of NPV, IRR, Gross $B / C$, Net $B / C$, $\mathrm{PV}^{\prime} / \mathrm{K}$, Payback period changes, $\mathrm{Y}_{1}$ is cost production, selling price, and production after changes; $Y_{0}$ is cost production, selling price, and production before changes, $\bar{Y}$ is the average of cost production, selling price, and production changes.

Analysis of marketing is done descriptively by observing the forms of mangosteen marketing channels conducted by farmers.

\section{RESULT AND DISCUSSION}

\section{General Description}

Geographically, Olumokunde Village is in the coordinate position of $-1.905319,120.887695$ with a height of $650 \mathrm{~m}$ above sea level. The total area of the village is 1,689 ha or $9.51 \%$ of the East Pamona District, with a distance of $11 \mathrm{~km}$ and from the regency capital (Poso) of $102 \mathrm{~km}$ (BPS Kabupaten Poso, 2017). The location of Olumokunde village is quite strategic as it is connected by land transportations to other areas such as North Morowali Regency and Southeast Sulawesi Province.

According to Geographic Information System (GIS) analysis, it is known that most of the Olumokunde region is hilly areas with varying physiography, classified as follows: First, flat and slightly sloping topography (slope of 0 to $8 \%$ ) which covers 767.03 ha or $45.41 \%$ of the area. This area is predominantly used for residential and rice fields for the population. Second, slightly sloping topography (slope of 8 to $15 \%$ ) which covers 260.48 ha or $15.42 \%$ of the area. In general, this area consists of shrubs, and some are used for dryland plantations. 
Third, undulating topography (slope of 15 to 25\%) which covers 361.35 ha or $21.39 \%$ of the Olumokunde area. Generally, this area consists of open fields (grassland areas), hills, and shrubs. Fourth, steep topography (slope of 25 to $45 \%$ ) which covers 234.68 ha or $13.89 \%$ of the Olumokunde area. This area is relatively narrow, but its existence is spread over hills, shrubs, secondary dryland forests, and open fields. Fifth, very steep topography (slope above $45 \%$ ) which covers 65.57 ha or $3.88 \%$ of the area. It spreads over hills, primary and secondary dryland forests, and shrubs. This type of area is very prone to landslides or erosion so that serious conservation and protection efforts are needed.

Based on the land suitability condition map, there are about $20 \%$ of available land which allows for planning mangosteen development in Olumokunde, with the sloping level ranges from slightly sloping to bumpy or hilly.

In terms of climate, Olumokunde has an average annual rainfall that reaches 1,600 to $1,800 \mathrm{~mm}$. The average daily temperature ranges from 25 to $32^{\circ} \mathrm{C}$. This condition meets the requirements for growing mangosteen crops in the forms of ideal temperatures which are in the range of 22 to $32^{\circ} \mathrm{C}$ and 1,500 to $2,500 \mathrm{~mm}$ of rainfall that is evenly distributed throughout the year (Maloya, 2013).

Observation results confirm that generally, the type of soil in Olumokunde is alluvial. Land characteristic for mangosteen planting demonstrates suitability on classes S1 and S2 with soil fertility level as a limiting factor. According to land suitability status, forest area status, and land cover, it is projected that available real land for expansion target and mangosteen production improvement at Olumokunde is as large as 495.15 ha.

In terms of cultivation technical aspect, the Olumokunde people have had long enough experiences in mangosteen planting, so that these experiences become a strength factor to support the mangosteen development program. Based on data from the agricultural extension worker, there is about 50 ha of community garden land planted with mangosteen. The constraint of the current crop development is the difficulty in obtaining superior seeds resulting from shoot grafting techniques and the provision of rootstock seedlings. For one mangosteen plant, it needs an average of 1 to 2 seeds planted. The interviews with the community about potential aspects of production showed that from each tree harvested, 100 to $125 \mathrm{~kg}$ of fresh mangosteen can be obtained.

The quality ratio of fruit weight in $1 \mathrm{~kg}$ reaches 8 fresh mangosteens, while the potential weight of quality mangosteen is 5 fresh fruits per $\mathrm{kg}$. Therefore, the quality of mangosteen weight needs to be increased through improving the technical aspects of cultivation and applying adequate technology. Observations show that most farmers have not applied adequate input technology and tend not to work fully to maintain crops. The use of production inputs on mangosteen crops is not yet a concern of farmers. Farmers do not apply fertilizers or intensive care because they are influenced by the perception that mangosteen is only a side crop that does not require full attention. People cultivate plants not prepared for market orientation and for largescale businesses. They do not pay attention to both the quantity and quality of products that fit the market needs.

\section{Farm Income}

Income analysis of the mangosteen farm at Olumokunde is performed in Table 1 . The analysis is conducted to mangosteen plantation business model as large as $1 \mathrm{ha}$, which is assumed to have met management standards, particularly in terms of the application of cultivation techniques such as using superior seeds, fertilizing according to recommended dosages, controlling pests and diseases, and using labors for plant maintenance. Farm income is calculated for 25 years following the stipulated investment period in the plantation business. The selling price of mangosteen fruit from farmers to traders is set at Rp10,000 per $\mathrm{kg}$ according to the real price at the time of the study.

The estimation of investment costs of mangosteen seedling planting is as many as 17.34 million rupiahs which consist of production facility costs such as seedling, fertilizer, pesticide, labor, and land rent costs. From the first to the fourth year, the crops have not produced yet so that farmers have not received revenue, only spending operational costs for purchasing fertilizers and pesticides as well as paying labors and land rent. The average operational cost during the period is many as 12.58 million rupiahs per ha. 
Table 1. Business Projection of Mangosteen Farming in Olumokunde Village

\begin{tabular}{crrrr}
\hline Year & Revenue & $\begin{array}{c}\text { Cost } \\
\text { production }\end{array}$ & Income & $\begin{array}{c}\text { R/C } \\
\text { Ratio }\end{array}$ \\
\hline \multicolumn{4}{c}{$\ldots \ldots \ldots .}$. & million rupiahs.......... \\
0 & - & 17.34 & -17.34 & 0.00 \\
1 & - & 11.81 & -11.81 & 0.00 \\
2 & - & 13.00 & -13.00 & 0.00 \\
3 & - & 13.03 & -13.03 & 0.00 \\
4 & - & 12.28 & -12.28 & 0.00 \\
5 & 6.00 & 14.13 & -8.13 & 0.43 \\
6 & 12.00 & 14.88 & -2.88 & 0.81 \\
7 & 24.00 & 16.36 & 7.64 & 1.47 \\
8 & 31.50 & 16.36 & 15.14 & 1.93 \\
9 & 42.00 & 19.47 & 22.53 & 2.16 \\
10 & 50.00 & 19.10 & 30.80 & 2.62 \\
11 & 65.00 & 19.74 & 45.27 & 3.29 \\
12 & 70.00 & 20.11 & 49.89 & 3.48 \\
13 & 83.00 & 20.11 & 62.89 & 4.13 \\
14 & 92.00 & 20.11 & 71.89 & 4.58 \\
15 & 105.00 & 21.84 & 83.16 & 4.81 \\
16 & 110.00 & 21.84 & 88.16 & 5.04 \\
17 & 120.00 & 21.84 & 98.16 & 5.49 \\
18 & 126.50 & 22.59 & 103.91 & 5.60 \\
19 & 123.00 & 22.59 & 100.41 & 5.45 \\
20 & 119.80 & 22.59 & 97.21 & 5.30 \\
21 & 111.50 & 21.09 & 90.41 & 5.29 \\
22 & 107.80 & 21.09 & 86.71 & 5.11 \\
23 & 104.00 & 21.09 & 82.91 & 4.93 \\
24 & 100.00 & 21.09 & 78.91 & 4.74 \\
25 & 93.50 & 20.11 & 73.39 & 4.65 \\
\hline
\end{tabular}

Starting in the fifth year, operational costs incurred are increasing as a consequence of the enhanced use of production facilities. Crops entering the mature phase require more amounts of fertilizer to support plant growth. The use of insecticides and fungicides is enhanced to prevent pests and diseases. Also, labor use is coupled to intensify crop farming and fruit harvesting processes. The highest operational costs incur in the 18th until the 20th year, which is related to high-level production in those years. Production costs begin to decrease in the 21st year along with the decline in mangosteen production. Farmers make adjustments to the use of production facilities so that the decline in farm income is not too significant. The intended adjustment is to reduce the use of insecticides and labors for fertilizing and harvesting.

Mangosteen fruit production reaches its peak when the crop is 18 years old. It is the time when mangosteen farm gets the highest income of 103.91 million rupiahs per ha. With the decline in mangosteen production after the 19th year, the farm profit has also decreased to reach the amount of 73.39 million rupiahs per ha in the 25th year.
In year 0 (initial investment) up to the fourth year, the value of $\mathrm{R} / \mathrm{C}$ Ratio $=0$, because the farm has not received revenue and only spending operational costs for unproductive crops. R/C Ratio when the crops are 5 to 6 year-aged is still less than 1 because the revenue obtained cannot cover operational expenses. But since the 7th year onwards the value of $R / C$ Ratio has exceeded 1 which means that the amount of revenue is higher than that of operational costs. The highest R/C Ratio of 5.6 is achieved in the 18th year, which means that each production cost expended of 1 unit will cause a revenue gain of 5.6 units. R/C Ratio value starts to decrease in the 19th year until reaches 4.649 in the 25th year. However, the value of R/C Ratio is still more than 1 , so that mangosteen farm still has economic feasibility.

\section{Farm Investment}

The values of investment feasibility indicators for mangosteen commodity development in Olumokunde are shown in Table 2. The NPV as many as 87.496 million rupiahs on investment rate of $14 \%$ is positive, which means that the investment is feasible to be conducted. The value indicates that the difference between benefit (revenue) and cost (expense) that is measured according to current money value is as many as 87.496 million rupiahs. The Gross B/C Ratio of 1.694 demonstrates the ratio between the amount of gross revenue and the amount of gross cost which the values are calculated at this time. Each gross expenditure (in the form of capital costs of initial investment costs, operational costs, and maintenance costs) of 1 unit will provide gross revenue (total production value and the investment residual value at the end of the economic life of the business) of 1.694 units. Based on this indicator, the investment is feasible to be conducted.

Table 2. Investment Feasibility of Mangosteen Farming

\begin{tabular}{lr}
\hline Feasibility criteria & Value \\
\hline NPV (million rupiahs) & 87.496 \\
Gross B/C Ratio & 1.694 \\
Net B/C Ratio & 2.476 \\
PV'/K & 6.047 \\
IRR (\%) & 19.784 \\
Payback period (year) & 10.950 \\
\hline
\end{tabular}

discount factor $=0.14$

The value of the Net $B / C$ Ratio of 2.476 is positive, which indicates a feasible investment. The value points out that the ratio between the amount 
of net revenue and the amount of net cost is 2.476 where each expenditure of 1 unit will provide revenue of 2.476 unit. The profitability ratio of 6.047 is positive as well, indicating that each capital expenditure of 1 unit will provide profit for business as many as 6.047 units.

The IRR value of $19.784 \%$ is higher than the assumed interest rate which is $14 \%$. This shows that it is more profitable for entrepreneurs to invest because the mangosteen farm will provide a return to the capital invested by $19.784 \%$. Meanwhile, the payback period of 10.95 years means that all expenses will be returned within 10 years and 11 months. The payback period is smaller than the investment life ( 25 years) so that the investment is feasible to be implemented.

\section{Farm Sensitivity}

Sensitivity analysis is used to find out the change of both internal and external factors which influences the values of revenue and cost production on investment criteria. The factor change includes the increase in cost production, the decrease in the selling price, and the decrease in production. Those are the most dominant factors that change at certain times. An increase in the production cost of $10 \%$ is assumed to correspond to the inflation rate which causes a rise in the price of production factors. A reduction in mangosteen selling price by $20 \%$ is to respond overproduction above the market capacity, especially during the main harvest. A $20 \%$ reduction in mangosteen production is assumed to occur if the production quantity does not achieve the target due to technical factors such as climate anomalies or pest and crop disease attacks. The result of sensitivity analysis is shown in Table 3.

An increase in production costs of $10 \%$ per year causes the NPV, Gross B/C, Net B/C, PV'/K, and IRR to decrease, while the payback period increases. NPV and Net B/C are sensitive to changes, whereas other indicators are not. The increase in cost production influences the ability of farmers to buy or to pay production factors. If production and fruit selling price is assumed to be constant, the increase in cost production will reduce the farm profit. Nevertheless, because all investment indicators still have positive values, the investment is still feasible to be conducted.

Table 3. The Sensitivity Analysis of Mangosteen Farming

\begin{tabular}{|c|c|c|c|c|c|}
\hline No & Changes that affect & Before change & After change & $\begin{array}{c}\text { Sensitivity } \\
\text { Rate }\end{array}$ & Result $^{\mathrm{a}}$ \\
\hline \multirow[t]{7}{*}{1} & Cost production raises $10 \%$ & & & & \\
\hline & NPV (million rupiahs) & 87.495 & 76.630 & 1.390 & S \\
\hline & Gross B/C & 1.694 & 1.560 & 0.865 & NS \\
\hline & Net $B / C$ & 2.476 & 2.191 & 1.282 & $\mathrm{~S}$ \\
\hline & $\mathrm{PV}^{\prime} / \mathrm{K}$ & 6.047 & 5.420 & 0.965 & NS \\
\hline & IRR (\%) & 19.784 & 19.291 & 0.265 & NS \\
\hline & Payback period (year) & 10.950 & 11.660 & 0.583 & NS \\
\hline \multirow[t]{7}{*}{2} & Fruit price decreases $20 \%$ & & & & \\
\hline & NPV (million rupiahs) & 87.495 & 44.747 & 2.910 & S \\
\hline & Gross B/C & 1.694 & 1.355 & 1.005 & $\mathrm{~S}$ \\
\hline & Net $B / C$ & 2.476 & 1.733 & 1.589 & $\mathrm{~S}$ \\
\hline & $\mathrm{PV}^{\prime} / \mathrm{K}$ & 6.047 & 3.581 & 2.305 & $S$ \\
\hline & IRR (\%) & 19.784 & 18.121 & 0.397 & NS \\
\hline & Payback period (year) & 10.950 & 12.090 & 0.520 & NS \\
\hline \multirow[t]{7}{*}{3} & Production decreases $20 \%$ & & & & \\
\hline & NPV (million rupiahs) & 87.495 & 67.505 & 2.706 & S \\
\hline & Gross B/C & 1.694 & 1.536 & 1.026 & $S$ \\
\hline & Net $B / C$ & 2.476 & 2.122 & 1.616 & $\mathrm{~S}$ \\
\hline & $\mathrm{PV}^{\prime} / \mathrm{K}$ & 6.047 & 4.894 & 2.211 & $\mathrm{~S}$ \\
\hline & IRR (\%) & 19.784 & 19.132 & 0.352 & NS \\
\hline & Payback period (year) & 10.950 & 11.940 & 0.736 & NS \\
\hline
\end{tabular}

The reduction of mangosteen selling price by $20 \%$ causes the NPV, Gross B/C, Net B/C, PV'/K, and IRR to decrease, while the payback period increases. Changes in the values of these indicators are far greater than changes due to increases in production costs. NPV, Gross B/C, Net $\mathrm{B} / \mathrm{C}$, and $\mathrm{PV}^{\prime} / \mathrm{K}$ are sensitive to change, while IRR and payback period are not. This indicates that farm sensitivity is greater 
against falling prices compared to rising production costs. If it is assumed that production and production costs are constant, then the decline in selling price will cause a reduction in profits which is far greater than the decline in profits due to rising production costs. However, in terms of investment feasibility, the values of the positive feasibility criteria demonstrate that investment is still feasible.

The decrease in mangosteen production of $10 \%$ also causes the NPV, Gross B/C, Net B/C, $\mathrm{PV} / \mathrm{K}$, and IRR to decrease, while the payback period increases. IRR and payback period is not sensitive against change, but the other variables are. However, sensitivity due to production reduction is still smaller than that of price decline. Production reduction causes a decrease in farm profit, but the investment is still feasible because of the positive values of feasibility indicators.

\section{Marketing}

There are two models of mangosteen marketing channels at Olumokunde which can be drawn as follows. First, direct marketing. In this model, farmers sell mangosteen directly to consumers at little stalls they build on the roadside. Mangosteen buyers generally are people who travel and cross the Trans Sulawesi road, including Olumokunde Village. The prevailing selling price between farmers and consumers at the time of this study was Rp10,000 per $\mathrm{kg}$.

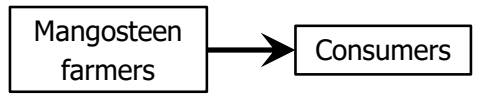

Figure 1. Direct marketing

The second, indirect marketing. In this model, farmers sell the fruit in a large amount to local wholesalers who then sell the fruits to consumers. The wholesalers bring the products outside the village because mangosteen consumers spread in quite larger areas. The local market for mangosteen products is Poso Regency (Tentena, Poso, and surrounding areas), while inter-provincial sales reach Mangkutana region, South Sulawesi Province. The prevailing selling price between farmers and wholesalers at the time of this study was Rp10,000 rupiahs per $\mathrm{kg}$, whereas the selling price between wholesalers and consumers could achieve Rp12,000 to $\mathrm{Rp} 15,000$ per $\mathrm{kg}$.
Based on the study conducted by Naseer et al. (2019), both direct and indirect mangosteen marketing could be included in the traditional supply chain category, which is a supply chain connecting farmers as the producer and local retailers, intermediaries, and markets as the channel to sell their fruit products. De Fazio (2016) mentioned it as the short supply chain. The studies pointed out that the extension of the supply chain had produced a decrease of its share of added value to the benefit of the farmers, and as a consequence, had excluded many small producers from the market.

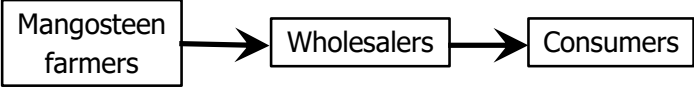

Figure 2. Indirect marketing

Both of these marketing channel models give convenience for farmers to sell their product to consumers. In direct marketing, consumers go directly to producers to make transactions. There are several advantages obtained by consumers. First, producers commonly allow consumers to sample some of the fruit for free. Second, mangosteen fruit is generally sold as fresh fruit. If consumers want to buy in large quantities, producers usually allow them to pick fruit directly on the tree. Therefore through direct marketing, the opportunity for consumers to get fresh mangosteen is greater. As for producers, they do not have to spend marketing cost to sell their products.

In indirect marketing, fruit wholesalers come to producers' locations to buy harvested fruit. Benefits received by producers through this marketing model are: (i) producers do not need to pay for distributing their products, (ii) producers do not necessarily bear the risk of damage to mangosteen fruit products if stored for more than 5 days without special treatments. The nature of mangosteen is perishable. At the farmer level, freshly harvested fruits are simply packaged in sacks to be sold to wholesalers, so that the risk of quality degradation is high.

\section{Research Implication}

The local government's plan to develop Olumokunde as Mangosteen Village in the large scale product development is needed. The development of large-scale mangosteen commodities requires market expansion, not only to meet local or regional 
demands but also to export overseas. According to Muslim \& Nurasa (2011), mangosteen export has a good opportunity because there are no quotas, and the demand volume from international consumers has not yet been fulfilled. However, product competition in international markets today are increasingly tight, where consumers generally prefer high-quality products at lower prices. Therefore, it is very essential to form and strengthen the fruit supply chain, particularly to design product supply, to determine product quality, and to transport the product until it reaches the final consumers.

The supply chain is an integrated process of a product since it is in the form of raw materials until it is converted into a finished product and finally sent to consumers (Deveriky et al., 2015). The formation and strengthening of the mangosteen supply chain at Olumokunde can be pursued through the following steps. First, the formation of farmer groups as a forum for cooperation and knowledge sharing among farmers so that they can carry out mangosteen cultivation in a professional manner. In the group, farmers need to be coordinated to work in the intensive assistance on crop management and postharvest handling. Thus, products will be produced with a high-quality standard at a reasonable selling price. Furthermore, farmers can coordinate to maintain production stability to prevent markedly changes in sales prices and market situations (Puspitaningrum \& Gayatri, 2019). The result of this study indicates that changes in production quantity are very sensitive, easily affecting farmers' income and the feasibility criteria for mangosteen farming.

Second, the establishment of farmer cooperative as buffering for farmers' mangosteen product, capital provider, and distributor of production facilities needed by farmers such as fertilizers and pesticides. Farmer cooperative then develops a standard for receiving mangosteen fruit products to be marketed. The cooperative should be equipped with facilities such as sorting, post-harvest handling, grading, and packaging. The organization mechanism functions of cooperative should be highlighted on to support of innovation creation, capital formation, agribusiness chain sustaining, and improving the cluster of the production system (Soetriono, Soejono, Zahrosa, Maharani, \& Hanafie, 2019).

Third, the active role of the local government in facilitating development program in the forms of (i) the provision of competent agricultural extension agents who have the role of providing technical guidance about mangosteen cultivation to farmers, and (ii) the building of a cooperation network with exporting companies that will buy mangosteen fruit products from farmer cooperative with export quality standards which are set.

Fourth, the implementation of researches by local universities regarding the study of mangosteen farming development in terms of agronomic, social, economical, and environmental aspects, which can support the improvement of product quality and efficiency of mangosteen farming.

\section{CONCLUSION AND SUGGESTION}

Mangosteen commodity development at Olumokunde Village meets the investment feasibility criteria. It is shown by indicators such as NPV of 87,496 million rupiahs, IRR of $19.8 \%$, and payback period of 10.95 years. Besides, the farm business of mangosteen estimate shows that the amount of revenue is higher than that of operational costs after the 7 th year.

There are two models of mangosteen marketing channels at Olumokunde, namely direct and indirect marketings. Both marketing channels provide advantages for farmers because they do not need to spend cost in selling their products. Commodity development on a large scale needs supply chain formation and strengthening to meet high-quality and high-competitive products.

This study suggests that mangosteen commodity development need reinforcement in various aspects such as empowerment of farmer group to increase productivity, the establishment of farmer cooperative to apply product quality standard, active participation of the local government to expand product market, and implementation of researches needs to improve farming development.

The limitation of this research is that feasibility analysis uses estimated data based on present situations, while future conditions are commonly uncertain. As a result, the analysis may not be the same as the actual values of investment feasibility criteria.

\section{ACKNOWLEDGMENT}

Gratitude and appreciation are expressed to Poso Regency Government through the Regional Research 
and Development Agency (Bapelitbangda) for providing funding for this research.

\section{REFERENCES}

Al-Sharafat, A., \& Al-Fawwaz, T. M. (2013). Economic analysis of different broiler farm capacities: a case study of Jordan. International Journal of Business and Management, 8(5), 41-47. http://dx.doi.org/10.5539/ijbm.v8n5p41

Ashari, T. D., Setiawan, B., \& Syafrial. (2015). Analisis simulasi kebijakan peningkatan ekspor manggis Indonesia. Habitat, 26(1), 61-70. https://doi.org/10.21776/ub.habitat.2015.026.1.8

Asmara, R., Hanani, N., \& Suryaningtyas, R. (2011). Analisis usahatani manggis dan faktor-faktor sosial ekonomi yang mempengaruhi keputusan petani memasarkan hasil usahatani manggis dengan sistem ijon. Agrise, 11(2), 129-137. Retrieved from https://agrise.ub.ac.id/index.php/agrise/article/vi ew/64

Asogwa, B. C., \& Okwoche, V. A. (2012). Marketing of agricultural produce among rural farm households in Nigeria: the case of sorghum marketing in Benue State. International Journal of Business and Social Science, 3(13), 269-277. https://doi.org/10.30845/ijbss

BPS Kabupaten Poso. (2017). Kabupaten Poso dalam Angka 2017. Badan Pusat Statistik Kabupaten Poso.

https://posokab.bps.go.id/publication/2017/08/13 /f47d7c34ec4a6c35ce37e456/kabupaten-posodalam-angka-2017.html

BPS Provinsi Sulawesi Tengah. (2017). Provinsi Sulawesi Tengah dalam Angka 2017. Badan Pusat Statistik Provinsi Sulawesi Tengah. Retrieved from https://sulteng.bps.go.id/publication/2017/08/11/ 355b7acc700bd2e89afd0084/provinsi-sulawesitengah-dalam-angka-2017.html

De Fazio, M. (2016). Agriculture and sustainability of the welfare: the role of the short supply chain. Agriculture and Agricultural Science Procedia, 8, 461-466.

https://doi.org/10.1016/j.aaspro.2016.02.044

Deveriky, D., Noer, M., \& Mahdi. (2015). Analisis manajemen rantai pasok (supply chain management) buah manggis oleh kelompok tani Kenagarian Sungai Talang Kabupaten 50 Kota Provinsi Sumatera Barat. Agribisnis Kerakyatan, 5(1), 22-30. Retrieved from http://jak.faperta.unand.ac.id/index.php/jak/articl e/view/62
Dhakal, S., Bhattarai, T., \& Dhakal, S. C. (2016). Financial feasibility of the biogas plant installation in Terai regions of Nepal. International Journal of Economics, Finance and Management Sciences, 4(3), $153-156$. https://doi.org/10.11548/j.ijefm.20160403.18.

Gogic, P., \& Ivanovic, S. (2013). Economic and financial analysis of investments in raspberry plantations. 50th Anniversary Department of Agricultural Economics, 326-335. https://doi.org/10.22004/ag.econ.161824

Gopalakhrisnan, S. (2013). Marketing system of mangoes in India. World Applied Sciences Journal, 21(7), 1000-1007. https://doi.org/10.5829/idosi.wasj.2013.21.7.286

Kusmayadi, I. F., Sujaya, D. H., \& Noormansyah, Z. (2017). Analisis kelayakan finansial usahatani manggis (Garcinia mangostana L.): studi kasus pada seorang petani manggis di Desa Cibanten Kecamatan Cijulang Kabupaten Pangandaran. Agroinfo Galuh, 4(2), 226-233. http://dx.doi.org/10.25157/jimag.v4i2.720

Kustiari, R., Purba, H. J., \& Hermanto. (2012). Analisis daya saing manggis Indonesia di pasar dunia: studi kasus di Sumatera Barat. Agro Ekonomi, 30(1), 81-107. http://dx.doi.org/10.21082/jae.v30n1.2012.81107

Maloya, U. (2013). Budidaya Tanaman Manggis (Garcinia mangostana). Dinas Pertanian dan Ketahanan Pangan Pemerintah Kabupaten Ciamis. Retrieved from http://dispertakp.ciamiskab.go.id/wpcontent/uploads/2017/07/BUDIDAYAMANGGIS.pdf

Muslim, C., \& Nurasa, T. (2011). Daya saing komoditas promosi ekspor manggis, sistem pemasaran dan kemantapannya di dalam negeri: studi kasus di Kabupaten Purwakarta, Jawa Barat. Agro Ekonomi, 29(1), 87-111. http://dx/doi.org/10.21082/jae.v29n1.2011.87111

Narakusuma, M. A., Fauzi, A. M., \& Firdaus, M. (2013). Rantai nilai produk olahan buah manggis. Manajemen dan Agribisnis, 10(1), 11-21. https://doi.org/10.17358/jma.10.1.11-21

Naseer, M. A. ur R., Mehdi, M., Ashfaq, M., Hassan, S., \& Abid, M. (2019). Effect of marketing channel choice on the profitability of citrus farmers: evidence from Punjab-Pakistan. Pakistan Journal of Agricultural Science, 56(4), 1003-1011. https://doi.org/10.21162/PAKJAS/19.8671 
Nuraniputri, U., Daryanto, H. K. S., \& Kuntjoro. (2016). Produksi manggis pada beberapa kelompok umur tanaman dan faktor-faktor yang mempengaruhi produksi manggis di Kabupaten Sukabumi, Jawa Barat. Agribisnis Indonesia, 4(1), 67-78. https://doi.org/10.29244/jai.20164.1.6778

Puspitaningrum, D. A., \& Gayatri, S. (2019). Farm partnership between farmers and the company in production and marketing of vegetables commodity. Journal of Socioeconomics and Development, 2(1), 45-53. https://doi.org/10.31328/jsed.v2i1.975

Rehman, S.-U., Selvaraj, M., \& Ibrahim, M. S. (2012). Indian agricultural marketing: a review. Asian Journal of Agriculture and Rural Development, 2(1), 69-75. Retrieved from http://www.aessweb.com/pdf-files/9-342(1)2012-AJARD-69-75.pdf

Santos, T. dos, Koestiono, D., \& Muhaimin, A. W. (2017). Feasibility study of coffee monoculture farming and jackfruit intercropping in Emera District of East Timor. Scholars Journal of Agriculture and Veterinary Science, 4(12), 513521. https://doi.org/10.21276/sjavs.2017.4.12.1
Saptana, Perwita, A. D., Darwis, V., \& Suhartini, S. H. (2018). Dinamika kelembagaan kemitraan usaha rantai pasok buah tropika berorientasi ekspor. Forum Penelitian Agro Ekonomi, 36(1), 45-61. http://dx.doi.org/10.21082/fae.v36n1.2018.45-61

Shruthi, K., Hiremath, G. M., \& Joshi, A. T. (2017). Financial feasibility of precision farming in paddy: a case study. Current Agriculture Research Journal, 5(3), 318-324. http://dx.doi.org/10.12944/CARJ.5.3.09

Soetriono, S., Soejono, D., Zahrosa, D. B., Maharani, A. D., \& Hanafie, S. R. (2019). Strategy and policy for strengthening the agricultural cooperative business in East Java, Indonesia. Journal of Socioeconomics and Development, 2(1), $12-22$. https://doi.org/10.31328/jsed.v2i1.886

Suminartika, E. (2017). The ability of mangosteen farmer to finance mangosteen farm in Subang District area. ICSAFS Conference Proceeding. 2nd International Conference on Sustainable Agriculture and Food Security. https://doi.org/https;//doi.org/10.18502/kls.v2i6. 1057 